\title{
The Concept of Colour Metaphor in Sundanese: A Semantic Cognitive Study
}

\author{
Muhammad Ivan Fauzi, \\ Nurul Khasanah, \\ Maria Dimitrij Angie Pavita \\ Diponegoro University \\ Semarang, Indonesia \\ Ifauzi696@gmail.com
}

Article History: Submitted on 21 th November 2020; Accepted on $15^{\text {th }}$ April 2021; Published on $30^{\text {th }}$ June 2021

\begin{abstract}
This paper is a qualitative descriptive study that aims to describe the concept of colour in Sundanese language. In this study, the authors used the free-tospeak listening method without involving the participants. To support the data collection, the author involves intuitive knowledge and reflective instropective as native Sundanese. In the method of analysis, the writer uses referential methods and semantic methods to describe and compare the relationship between metaphorical expressions as the source and the intended meaning of the target. The data taken are fragments of song lyrics, fragments of sentences from short stories, and proverbs. As a result, the authors found that in producing metaphors, humans have 3 things, experiences from their culture, semantic memory as vocabulary vocabulary, and cognitive processes. However, some colours like; bideung (black) sadness and courage, beureum (red) represents feelings of shame, anger and luxury, bodas (white) which symbolizes purity and happiness, konéng (yellow) represents smooth skin, béjo (green) which symbolizes fertility, prosperity and blue as a symbol of calm, happiness and hope.
\end{abstract}

Keywords: metaphors, cognitive semantics, sundanese language, conceptual metaphors 


\section{INTRODUCTION}

The use of metaphors in language life is very common. Not only in the figurative space, but also in the colloquial space so that the diction used is new and fresh. In language, humans have 3 processes namely psychological, physiological and physical. In the psychological process, humans must think in advance about what they want to say, what kind of sentences they will use and what words they will choose. After this psychological process occurs, a physiological process appears characterized by the presence of speech organs that work to produce speech. After that, a physical process occurs when the speech is accepted by the other person. In the psychological process, humans have creativity in speaking. Sentences produced by one person to another will be very diverse. This is related to semantic memory, namely semantic concepts (Collins and Qulillian in He (2011), and embodied experience, which are experiences he has had (Lakoff and Johnson, 2016), both of which are stored in the speaker's memory. Therefore, the choice of words and creativity of speakers will be very diverse. As previously explained that metaphors are generated based on human experience, vocabulary and cognitive processes, of course culture plays an important role in the acquisition of human experience. Every culture has its own uniqueness and uniqueness. Culture has the identity or characteristics of a group of people who inhabit an area. Culture is born from the habits of society carried out from generation to generation and will take root in human life which unconsciously affects human behavior. Such as the way humans interact, the way humans see things from their point of view, and so on. The culture that has been formed is what will provide experience for our capital to form metaphorical expressions.

Metaphor is a way of associating a concept with other related concepts (Wijana, 2015), metaphors can cover various aspects of everyday life, not only in terms of language, but also in our thoughts and behavior. The conceptual system that we have, both from the way we think and behave is basically a metaphor that occurs naturally. This paper is based on the theory of Lakoff and Johnson (in Yun Xu, 2015) which states that metaphors are a form of reflection of experiences experienced, felt and also thought by humans. All these experiences are stored in the brain and when it will produce metaphors, human semantic memory will work. This statement is reinforced by Saeed (in Indra, 2017) who states that language is an activity of cognition and linguistic competence that is supported by special forms of knowledge.(Umam \& Nirmala, 2020). Metaphor is the logical mapping of one domain (usually, but not always a concrete domain) to another domain (usually more abstract)(Fadhilah et al, 2019). The concept of colour in a metaphor, meaning must be interpreted based on certain similarities between primary and secondary meanings or between the conception of the source domain and the target domain where the target domain is more abstract than the source domain (Kövecses, 2006 in Wiradharma, 2016). 
The term colour does not refer to colour literally, but is used metaphorically. For example in English 'black hearted' "Black heart" means evil, something negative. Black is a taboo colour in western culture, and reflects the black magic that westerners believe in. As another example, the phrase "black goat" in Indonesian means 'someone who is considered an embarrassment to a family member'.

Many studies have discussed metaphors in terms of cognitive linguistics. As in the Cognitive Process in Metaphorical Expressions by Nirmala (2014) which discusses metaphors are a reflection of conceptualization groups based on experiences that the body can feel, based on characteristics, traits, strengths and functions. Then in Sekarsari and Haristiani (2016) in the Analysis of the Meaning of Kanyoku relating to colour, it discusses the study of colour and idioms in Japanese. Further research was carried out by(Wijana, 2015)in his research entitled "Metaphors Of Colours In Indonesian". This study describes the concept of colour metaphors in Indonesian. The results showed that the colour concept used was classified as chromatic and achromatic colours. Then the colour metaphor that is unique to Indonesia is sought for its relationship with aspects outside of language, such as environmental factors, history, religion, politics and social activities. The use of chromatic and achromatic colour metaphors in English and Indonesian did not find specific differences. However, there is a distinctive colour metaphor that exists in both English and Indonesian.

Further research was carried out by(Indra, 2017)in his research entitled "Semantic Analysis of Colour Metaphors for Minangkabau Language". This study describes the existence of the term colour and its connotations in the Minangkabau metaphor. Data was collected from native speakers and from books such as the Minangkabau Language Dictionary, Minangkabau Proverbs Language, randai texts, and lyrics of Minangkabau songs. Metaphorical colour expression is analyzed by relating it to its literal meaning and other factors such as physical, psychological, historical, and cultural. The findings of this study indicate that there are six colours found in metaphorical expressions, namely it 'black', putiah 'white, kulabu' gray ', sirah' red ', kunyiang' yellow ', and green' green '. Some colours, such as black, white, red, and yellow, have negative and positive connotations. However, other colours like gray and green only carry negative connotations. This expression of metabolic colour is unique in that it is largely influenced by many factors in Minangkabau language and culture. In this paper, the writer tries to describe the metaphorical meaning of colour in Sundanese which is certainly different from other languages.

Based on the explanation in the previous studies above, it can be concluded that this study can be a follow-up of those previous studies about metaphor and colour but there are differences in research focus because this study specifically analyzes the colour metaphor in sundanese. So, this research 
is different from those previous research studying about the colour metaphor in another language, while this research uses sundanese as the research focus.

\section{METHOD}

This research is semantic research which focuses on cognitive semantic study. This type of research is descriptive qualitative because this research will use words to figure out the results instead of numbers or other symbols. The object of this research is colour terms in sundanese which are considered as metaphor. Researchers started with data collection, data analysis, and presentation of data analysis. The data were taken randomly, namely from pieces of Sundanese song lyrics, Sundanese fragments of sentences from short stories, and Sundanese proverbs.The data were collected using nonparticipant observation (SBLC). All the-data were observed, identified, and selected according to the research problem which uses colour terms for metaphorical means in sundanese.

In the method of analysis, the writer uses referential methods and semantic methods to describe and compare the relationship between metaphorical expressions as the source and the intended meaning of the target. Next, the data were analyzed in-depth analysis process with a method of interpretation. The presentation of data analysis is done in narrative form. Narrative form presentation is divided into two types, namely formal and informal (Sudaryanto, 2015 in Sunarni \& Johana, 2019) This analysis was done informally because the presentation of the data analysis uses ordinary words that are easy to understand.

\section{FINDINGS AND DISCUSSION}

Based on the data analysis, there are 6 colour terms found in the Sundanese language that have metaphor. They are hideung (black), beureum (red), bodas (white), koneng (yellow), hejo (green), biru (blue). The data in this result are found from fragments of song lyrics, fragments of sentences from short stories, and proverbs. The explanation of the data will be discuss in this section.

\section{Hideung (Black)}

The colour black is often associated with negative qualities, and is associated with terrible, evil and illegal meanings(Weihua, 2017). Black also represents darkness, night, and despair. It's the color used to convey certainty and authority, and when used in opposition with white, it's a symbol of the eternal struggle between day and night, good and evil, and right and wrong. In the other hand, black is associated with power, fear, mystery, strength, authority, elegance, formality, death, evil, and aggression, authority, rebellion, and sophistication. Black is required for all other colors to have depth and 
variation of hue(Bourn, 2010). In Sundanese, the metaphorical meaning of black tends to be sad, something that makes you sad. In (1), the writer found a fragment of a song from Yayan Jatnika entitled 'Mega Hideung'

(1) Mega bideung ngalangkangan (black clouds step over) Cendeum sky sign arek. Rain comes (Cloudy sky is a sign of rain) Naha naon, my account is invited (Why. What are you looking for?) Kanyaah Kanyaah loves to lose (affection and love for me) Meureun kuring henteu ngalayah my treasure (Maybe I'm not wallowing in wealth)

This fragment of the song tells about the sadness of a man who was abandoned by a woman he loved because he was poor. That was the expression of dissapointed and the singer likens her state and mood to a cloudy sky with black clouds. The black colour metaphor is also found in the song 'Tong Diceungceurikan' (don't cry). The lyrics are as follows:

(2) Urang lir is like a puppet(we are like puppets) My malik na me is the puppeteer(our movements are regulated by the puppeteer)

Anu teu wasa teu weunang(We have no power

Beureum bideung kumaha dalang (Red black is up to the mastermind)

(3) Ras ka the gods, nu geus cuent ka nu bideung. (reminded of the unjust gods) (Murang -Maring, 1985: 61 (in Rahayu, 2017)

\section{(4) getih bideung}

In the lyric section (2), black means sadness, something that is not good in our lives that we must accept because it is God's destiny. Dalang is also a metaphor which means God. Apart from the meaning of sadness, another meaning of hideung is the injustice that the writer finds in the collection of short stories Murang-maring on the data (3). In Sundanese, cueut means 'onesided, unbalanced'. After being followed by the word hideung, this phrase turned out to be unfair. But it doesn't only mean sadness and ugliness, the black colour in (4) in Sundanese also means courage, regardless of anything.

\section{Beureum (Red)}

The color red is an intense color that is packed with emotion ranging from passionate, intense love to anger and violence — representing both cupid and the devil. It is a hot, strong, stimulating color that represents excitement and energy. Studies show that the color red can create physical effects such as elevated blood pressure, enhanced libido, increased respiratory rates, enhanced metabolism, increased enthusiasm, higher levels of energy, and increased confidence (Bourn, 2011). Red is usually associated with joyful 
celebrations and occasions.(Weihua, 2017). Generally, red symbolizes vitality, expansive character, burning heat, courage, danger, and so on(Wijana, 2015). In Western countries, red is the colour of life, as well as the colour of fire and blood. In English, "red" is used as a warning sign of some danger in most of the cases(Weihua, 2017). But in Sundanese, the metaphor of colour means shame, as in sentence (5) below:

(5) Nu dirérét beureum bari kalamas kélémés. (who glanced red while looking away (out of embarrassment) (Payung Butut, 2013: 9)

In data (5), the word beureum is a metaphorical word because it is followed by the word 'kalamas kélémés'. But context also plays an important role in metaphor. The word 'beureum' can also describe that the person is angry, as in the following sentence (6):

(6) Beungeutna immediately beat me due to emotion(red with emotion)

As well as being embarrassed and angry, the red metaphor in Sundanese also means luxury, as in the example of the following Sundanese proverb:

(7) Adean my horse beureum(proud of other people's loan (luxury) goods)

\section{(8) Bur beureum bur bideung, burung nangtung leumpang afternoon}

Beureum horse literally means 'red horse'. This is in accordance with the opinion. Weihua (2017)that red is usually associated with joyful celebrations and occasions. Another example that describes red as luxury is sentence (8), which literally means 'red, black, burning standing, day walking'. This proverb means' to live well with self-sufficiency 'in the first sentence, and' to dress nicely and trendy)

\section{Bodas (White)}

Generally, white is identified with purity and positivity, while a bride wearing white was often thought to convey the bride's virginity, blue was once a traditional color worn by brides to symbolize purity. White is the colour of snow. White conveys purity and cleanliness(Weihua, 2017). In the positives side, white can convey cleanliness, freshness, and simplicity. The color white often seems like a blank slate, symbolizing a new beginning or a fresh start. So that, in Sundanese, the metaphor of the white colour also symbolizes kindness, purity. As in sentence (9) below: 


\section{(9) Ateul white body bodas}

This sentence when seen literally means 'white itching white body'. However, the proverb means' someone who is clean in heart, has no evil intentions. Then, the white colour also symbolizes the unmarried girl, as in the song 'Mawar Bodas' by Doel Sumbang. Here are the lyrics:

\section{(10) Nu is important from nepi (important origin until) Ka where so and so on (to the place to be headed) Account Ngalongok rose bodas (want to meet white roses) $\mathrm{Nu}$ moal lila ka ala (which will soon be picked)}

This song tells the story of a man who returns from overseas because he wants to meet a girl in his village. The songwriter depicts a girl with roses, and white as a sign that the girl is not married.

(11) despairing of honey you eat bodas(Feeling flooded with honey, covered in white incense)

Apart from the meaning of holiness, the metaphor of the white colour in Sundanese means joy, happiness. Sentence (11) is a Sundanese proverb which means 'very happy, very happy'.

\section{Konéng (Yellow)}

There are not many Sundanese yellow metaphors. Yellow is associated with the sun and its life-giving warmth. Yellow also stands for caution, and it's used for traffic warning signs and traffic signals in nearly every country. Yellow is optimism and the cheerfulness of a sunny day. However, the Sundanese have a yellow concept to represent beautiful skin. As in the song 'runtah (trash)' from Doel Sumbang in the following data (12). This song is the orientation of beautiful women according to the Sundanese, namely smooth olive skin, not pale white.

(12) Cau shell koneng klir skin(yellow skin like banana peel)

Huntuna bodas tipung tarigu(teeth as white as flour)

Biwir beureum, beureum jawer hayam(red lips like a chicken's comb)

Chocolate coffee milk panon(brown eyes like coffee milk)

\section{Héjo (green)}

Green is a colour that is harmonious and synonymous with environmental growth. Green is a cool color that symbolizes nature and the natural world. Perhaps because of its strong associations with nature, green is often thought to represent tranquility, good luck, health, and jealousy (Yulianti, 2016) Due to the feel of spring, this colour defies any colour that refers to maturity(Wijana, 2015). Likewise in Sundanese, the metaphor of the green 
colour means fertility, prosperity. As in (13) which is a Sundanese proverb, it means 'the condition of a person who is having a lot of luck'.

(13) Leubeut héjo fruit leaves (thick green fruit leaves)

(14) Manéb mah héjo panon na ari kana duit téh. (your eyes are green when it comes to money)

Like the Indonesian metaphor, the word green when combined with the word 'eye' means someone who is very skilled with money.

\section{Biru Blue}

In Sundanese, the blue colour symbolizes calm, like looking at the sky. Blue represents the healing nature of water and the power of stormy seas. It's what separates bodies of land from one another, and it's a marker of loyalty and fidelity. Like many colors, our response to the color blue is complex and sometimes even contradictory (Yulianti, 2016).This is in line with the opinion of Weihua (2017) that blue is a natural colour that makes us calm. Blue is the colour of the sky, symbolizing the depth of the entity. The author found one of the blue metaphors in the Sundanese song 'Biruna Langit' by Yayan Jatnika on data (15):

\section{(15) Beantiful blue sky blue (blue sky like her love)}

Softly the wind na lir ragrag cintana(softly the wind is like falling love)

The song expresses the heart of a person who is in love which is likened to the blue sky containing joy and serenity. The blue colour implies a couple's hope for togetherness and happiness forever, like the sky that never changes colour.

So, from the explanation above, metaphorical colours expression in Sundanese explain symbols, situation, and condition of people in general. The context of it's colours can be love, nature, happiness, sadness, sign of unmarriage women, and many others. In producing metaphor, people have three things, they are; experiencess that related to everyday life, culture, and personal experiences. Second, semantic memory as vocabulary that related to mental space of each individual. The mental space of individual makes them directly understand the meaning and context of each lyrics. Third, cognitive process which is related to process and movements that affect mental contents of a person such as the process of thinking or operation of remembering something so that the lyrics or provebs of colours make anyone remebering something that affect them. 


\section{CONCLUSION}

From the research results above, it can be concluded that metaphor is a way of associating a concept with other related concepts. In producing metaphors, humans have 3 things, experiences from their culture, semantic memory as vocabulary vocabulary, and cognitive processes. Every culture has a different metaphor concept. For example, the colour metaphor in Indonesian and English is certainly different. Likewise Sundanese. In Sundanese, metaphorical expressions use quite a lot of colour vocabulary. The author found the colour hideung (black) which depicts sadness and courage, beureum (red) represents feelings of shame, anger and luxury, bodas (white) which symbolizes purity and happiness, konéng (yellow) represents smooth skin, héjo (green) which symbolizes fertility, prosperity and blue as a symbol of calm, happiness and hope.

\section{REFERENCES}

Fadhilah, N., Rais, W. A., \& Purnanto, D. (2019). Metaphor analysis on Colour Lexicon with Plant Attributes in Madurese Language. 13(August), 191-199. https://doi.org/10.21512/lc.v13i3.5769

He, G. (2011). A comparative study of color metaphors in english and Chinese. Theory and Practice in Language Studies. https://doi.org/10.4304/tpls.1.12.1804-1808

Indra, Y. (2017). Semantic Analysis of Colour Metaphors for Minangkabau Language. Metalingua.

Lakoff, G. (2016). Conceptual Metaphor: The Contemporary Theory of Metaphor. Edited by Dirk Geeraerts. Cognitive Linguistics: Basic Reasings. Berlin: Walter de Gruyter

Nirmala, D. (2014). Cognitive Process in Metaphorical Expressions. Semarang: Diponegoro University Parole, 4

Sekarsari, W., \& Haristiani, N. (2016). Analysis of the Meaning of Kanyoku related to colour: Cognitive Linguistic Study. Journal of Language and Literature Education, 16(1), 96-109

Umam, K., \& Nirmala, D. (2020). Colour Metaphorin English and Indonesian Song Lyrics. RETORIKA: Jurnal Babasa, Sastra, Dan Pengajarannya, 13(1), 66. https://doi.org/10.26858/retorika.v13i1.11504

Weihua, Y. (2017). A Discussion of Colour Metaphors From the Perspective of Cognition and Culture. 15 (1), 19-23. https://doi.org/10.3968/9837

Wijana, IDP (2015). METAPHOR OF COLOURS IN INDONESIAN. Journal of Humanities. https://doi.org/10.22146/jh.v27i1.6397

Wiradharma, G., \& S, A. T. W. (2016). Metafora Dalam Lirik Lagu Dangdut: Kajian Semantik Kognitif. Arkhais - Jurnal Ilmu Bahasa Dan Sastra Indonesia. https://doi.org/10.21009/arkhais.071.02

Yun Xu, Xu. (2015) Warna Dalam Bahasa Mandarin Dan Bahasa Indonesia: Sebuah Kajian Linguistik Antropologis.

Yulianti, S. (2016). Kosakata warna dalam Bahasa sunda. Ranah Volume 5, Nomor 1, 